\title{
Tumor-infiltrating T lymphocytes: friends or foes?
}

\author{
Ping Yu and Yang-Xin Fu \\ Department of Pathology and Committee on Immunology, University of Chicago, Chicago, IL, USA
}

\begin{abstract}
The prognostic significance of tumor-infiltrating lymphocytes (TILs) has been a longstanding topic of debate. In cases where TILs have improved patient outcome, T lymphocytes are recognized as the main effectors of antitumor immune responses. However, recent studies have revealed that a subset of $\mathrm{CD}^{+}{ }^{+} \mathbf{T}$ cells, referred to as $\mathrm{CD}^{+}{ }^{+} \mathrm{CD25}^{+}$regulatory $\mathrm{T}$ cells (Treg), may accumulate in the tumor environment and suppress tumorspecific T-cell responses, thereby hindering tumor rejection. Hence, predicting tumor behavior on the basis of an indiscriminate evaluation of tumor-infiltrating $T$ cells may result in inconsistent prognostic accuracy. The presence of infiltrating $\mathrm{CD4}{ }^{+} \mathrm{CD} 25^{+}$Treg may be detrimental to the host defense against the tumor, while the presence of effector $\mathrm{T}$ lymphocytes, including $\mathrm{CDB}^{+} \mathrm{T}$ cells and nonregulatory $\mathrm{CD4}{ }^{+}$helper $\mathrm{T}$ cells may be beneficial. Enhanced recruitment of antitumor effector T lymphocytes to tumor tissue in addition to inhibition of local Treg, may therefore be an ideal target for improving cancer immunotherapy. This article reviews the antitumor functions of T-lymphocytes, with special attention given to $\mathrm{CD4}^{+}$regulatory $\mathrm{T}$-cells within the tumor environment.
\end{abstract}

Laboratory Investigation (2006) 86, 231-245. doi:10.1038/labinvest.3700389; published online 30 January 2006

Keywords: tumor-infiltrating lymphocytes; tumor immunology; immunotherapy; CD4 ${ }^{+} \mathrm{T}$ cells; $\mathrm{CD}^{+}{ }^{+} \mathrm{T}$ cells; $\mathrm{CD} 4{ }^{+} \mathrm{CD} 25^{+}$regulatory $\mathrm{T}$ cells

Ever since the notion of tumor antigenicity emerged as an irrevocable concept, ${ }^{1-7}$ the failure of immunocompetent hosts to reject antigenic cancers has been a longstanding conundrum in the tumor immunology field. ${ }^{8-11}$ Despite the troubling failure of the host to reject antigenic tumors, evidence of an antigen-specific immune response is undeniable. ${ }^{12,13}$ Lymphocytes infiltrate many murine and human tumors, yet to the consternation of many immunologists, spontaneous regression rarely occurs. Even the significance of inflammatory cells within or surrounding solid tumors has been the subject of conflicting reports. ${ }^{14-17}$

Several studies have demonstrated that elevated levels of tumor-infiltrating lymphocytes (TILs) are associated with better prognosis. ${ }^{14,15,17}$ However, a sweeping assumption that the influx of lymphocytes to the tumor site is invariably beneficial to the patient may be inappropriate. Recent studies suggest that the type, not the quantity, of tumor-infiltrating cells may be a more critical determinant for the

Correspondence: Dr P Yu, MD, or Dr Y-X Fu, MD, PhD, Department of Pathology and Committee on Immunology, The University of Chicago, 5841 S. Maryland, MC3083, Chicago, IL 60637, USA.

E-mail: pingyu@uchicago.edu or yfu@uchicago.edu

Received and accepted 14 December 2005; published online 30 January 2006 prognosis. ${ }^{16}$ For example, infiltrating regulatory $\mathrm{CD}^{+}$cells can be more detrimental than favorable. ${ }^{16}$ Specifically, this subpopulation of TILs may impair the host's ability to defend against malignant cells. ${ }^{18-29}$ Likewise, antitumor lymphocytes migrating to the tumor site may become compromised once within the tumor milieu, or may adversely adapt to the suppressive environment to promote growth instead of regression. This review will rigorously examine the subtypes of $\mathrm{T}$ lymphocytes that behave either as friends or as foes in antitumor immunity. A detailed understanding of the functional peculiarities of individual $\mathrm{T}$ lymphocyte subtypes may explain the paradox that the presence of TILs does not always correlate with improved prognosis and may also allow the development of targeted approaches that specifically augment antitumor immune responses. ${ }^{17,30-38}$

\section{Antitumor functions of T lymphocytes}

The mature T-cell population is composed of $\alpha \beta \mathrm{T}$ cells expressing CD4 or CD8, and the $\mathrm{CD} 4^{-} / \mathrm{CD} 8^{-} \gamma \delta$ T-cell receptor (TCR)-expressing cells. The unique function of $\mathrm{CD}^{+}$and $\mathrm{CD}^{+}{ }^{+}$T cells is dictated by the expression of these coreceptors, CD4 or CD8, for which the ligand is the $\beta 2$ domain of the major histocompatibility complex (MHC) class II 
molecule ${ }^{39}$ and the $\alpha 3$ domain of MHC class I molecules ${ }^{40}$ respectively. Due to these specificities, the $\alpha \beta$ TCR of $\mathrm{CD}^{+} \mathrm{T}$ cells is restricted to the recognition of antigens presented by MHC class I molecules and the $\alpha \beta$ TCR of $\mathrm{CD}^{+} \mathrm{T}$ cells to antigens presented by MHC class II molecules. However, relatively little is known about the function of $\gamma \delta \mathrm{T}$ in antitumor immunity so far; thus, this review will mainly focus on the $\alpha \beta$ T cells.

The important role of $\mathrm{T}$ cells as effectors in antitumor immunity was first shown in numerous murine models. For instance, UV light-induced tumors are rejected regularly by normal mice, but grow progressively in the absence of T cells. ${ }^{4-43} \mathrm{In}$ human melanoma patients, a brisk TIL response is also of prognostic significance. It has also been demonstrated convincingly that T-cell-mediated immunity is essential for the rejection of virally and chemically induced tumors. ${ }^{5,7,4-47}$ For example, with murine model tumors induced by the chemical carcinogen methylcholanthrene (MCA), intravenous injection of immune cells, but not of immune serum, can transfer systemic tumor-specific immunity into sublethally irradiated mice. ${ }^{5}$ These results are consistent with studies showing that the protective immunity against a plasma-cell tumor was abolished by prior depletion of T-lymphocytes via anti-T-cell antibodies and complement. ${ }^{47}$

The importance of $\mathrm{T}$ cells in tumor immunity has also been implicated in human studies, albeit with discernable limitations. While most murine tumor models have the advantage of utilizing antigenspecific $\mathrm{T}$ cells generated from tumor-free syngeneic mice, generating a human homolog is not feasible. Thus, in human studies, $\mathrm{T}$ lymphocytes are isolated from peripheral blood ${ }^{48,49}$ or from the tumor $^{50}$ of cancer patients. Such T cells can react in vitro with autologous cancer cells. ${ }^{51}$ Utilizing adoptive transfer of in vitro expanded TIL in combination with chemotherapy, recent clinical trials have shown up to $50 \%$ positive response rates in selected patients with late-stage aggressive cancers. ${ }^{52-55}$

\section{CD8 $^{+} \mathbf{T}$ cells in tumor immunity}

While the significance of lymphocytes in tumor immunity is rarely disputed, the relative importance of various T-cell subsets in tumor rejection is the subject of great controversies. ${ }^{56}$ Broadly speaking, since cancer is a disease caused by an array of mutations in various types of cells, differences in the T-cell subsets required for mediating tumor rejection are not altogether surprising. One such subset is the $\mathrm{CD}^{+}{ }^{+}$cytotoxic $\mathrm{T}$ lymphocytes (CTLs). Most tumors are positive for MHC class I but negative for MHC class II, and CTLs are able to induce tumor killing upon direct recognition of peptide antigens, presented by the tumor's MHC class I molecules. Thus, the initial attention to antitumor immune responses was preferentially given to $\mathrm{CD}^{+} \mathrm{T}$ cells. That the $\mathrm{CD}^{+} \mathrm{T}$ cells are critical effectors against tumor cells is further supported by numerous studies in murine models. For instance, in UV light-induced tumors the CD8 ${ }^{+}$ cytolytic T-cell subset appears to be required for rejection. ${ }^{41}$ Murine CTLs that kill tumor targets in vitro can be freshly isolated from mice after repeated intraperitoneal injection of antigenic tumor cells, or can be generated ex vivo in a 7-day mixed lymphocyte-tumor cell culture. Elimination of CD8 ${ }^{+}$ T cells from mice-either via depleting antibodies or using genetic knockout mice-can, at least partially, abrogate the antitumor immunity induced by most cancer vaccines. ${ }^{57-60}$ Consistent with the murine models, clinical data from cancer patients uphold the importance of $\mathrm{CD}^{+} \mathrm{T}$ cells in bringing forth an antitumor response. Adoptive transfer studies of in vitro stimulated $\mathrm{CD}^{+}{ }^{+} \mathrm{T}$-cell lines and $\mathrm{CD}^{+}$clones specific for tumor antigens effectively mediate antitumor immunity when transferred back into tumor-bearing hosts. ${ }^{10,13,52}$ Furthermore, recent reports suggest that immunization, using either adjuvant or dendritic cells (DCs) with pure tumor peptides, can result in productive antitumor immunity that is restricted by MHC class I. ${ }^{61,62}$ Taken together, CD8 ${ }^{+} \mathrm{T}$ cells in tumor immunity can be unquestionably heralded as one of the principal subsets of $\mathrm{T}$ cells that constructively mediate an effective antitumor response (see Figure 1).

\section{Helper and effector role of $\mathrm{CD}^{+}{ }^{+} \mathrm{T}$ cells}

Undeniably, $\mathrm{CD}^{+} \mathrm{T}$ cells are an integral part of adaptive immunity, but the specific role they play in mounting an antitumor response remains a subject of debate. The critical function of $\mathrm{CD} 4{ }^{+} \mathrm{T}$ cells in promoting immunity has been consistently demonstrated by vaccine and challenge experiments employing antibody-mediated depletion of CD4 ${ }^{+} \mathrm{T}$ cells, or by using CD4-knockout mice. ${ }^{57-60,63-68}$ More importantly, similar to CD8 ${ }^{+}$T cells, tumor-specific $\mathrm{CD}^{+}{ }^{+} \mathrm{T}$ cells that can recognize tumor antigens do exist and data show that these $\mathrm{T}$ cells migrate to the tumor site in both murine and human cancers. ${ }^{69-71}$ However, complications arise when the accumulation of CD4 ${ }^{+}$T cells within the tumor microenvironment during tumor progression seemingly hinders the effector function of $\mathrm{CD}^{+}{ }^{+} \mathrm{T}$ cells. ${ }^{18,72-75}$ The hallmark phenotype of the CD4 ${ }^{+} \mathrm{T}$ cell that impedes the antitumor response seems to be attributable to a regulatory function. ${ }^{16,76-79}$ This paradoxical dualism of $\mathrm{CD}^{+} \mathrm{T}$ cells obligates further differentiation of this subtype into helper and regulatory CD4 ${ }^{+}$ T cells.

Although $\mathrm{CD}^{+}{ }^{+} \mathrm{T}$ cells have been shown to be sufficient to eliminate tumor cells in the absence of $\mathrm{CD}^{+}$T cells in some tumor models, ${ }^{70,80-83}$ it is more often the case that both $\mathrm{CD}^{+}$and $\mathrm{CD}^{+}$are required for effective tumor rejection to occur. ${ }^{84}$ In part, this is due to a substantial portion of tumor 


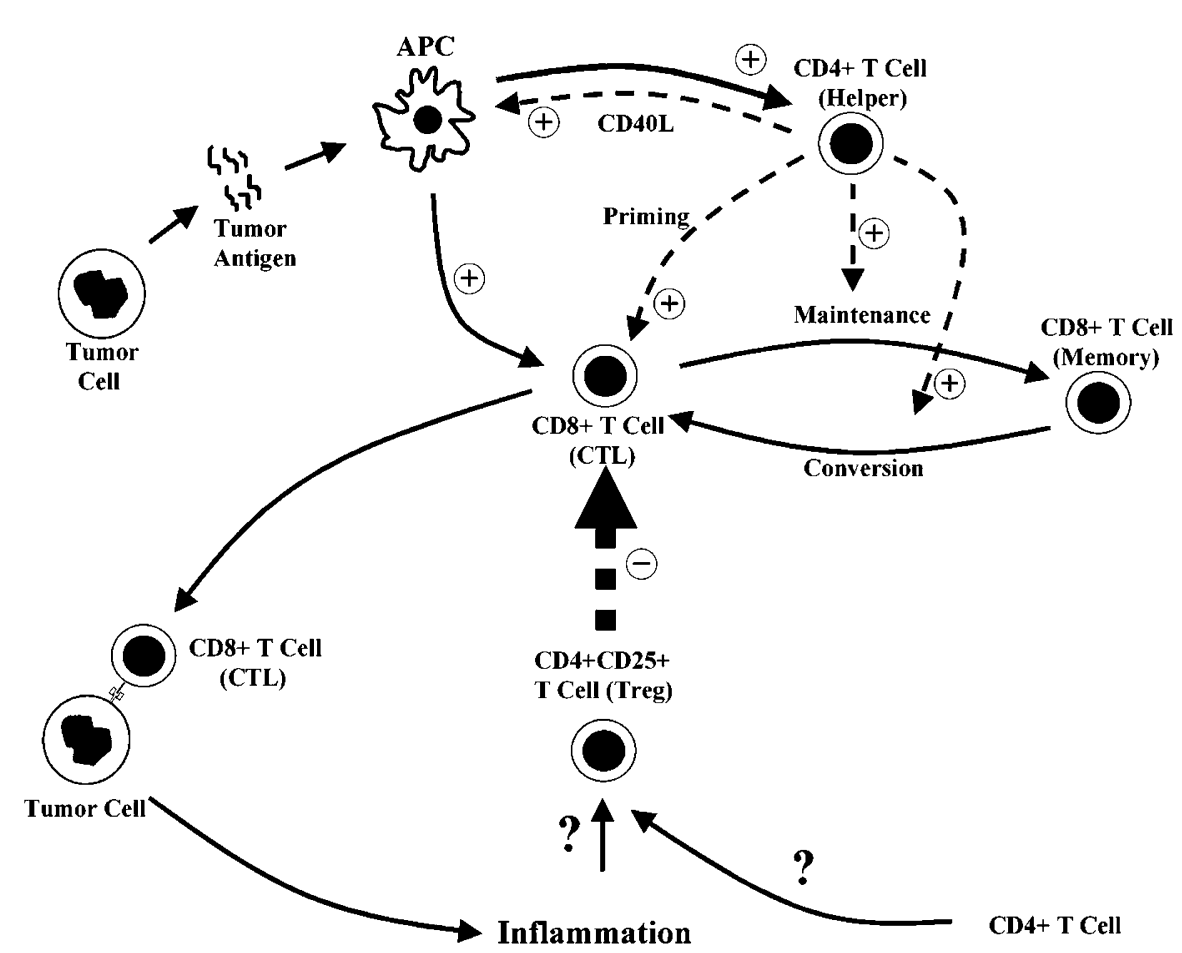

Figure 1 Proposed functions of T cells in tumor immunology. The CD8 ${ }^{+}$cytotoxic lymphocyte (CTL) is a well-documented effector of tumor immunity, interacting with tumor cells through the MHC-I receptor (not shown). CD4 ${ }^{+}$T-helper cells can help prime CTL, both directly and through stimulation of professional antigen-presenting cells (APC). The APC, in turn, present tumor antigens to the CTL. Both effects of $\mathrm{CD} 4^{+}$T-helper cells promote the host immune response to tumors. An additional proposed effect of CD4 ${ }^{+}$helper cells is the maintenance of a subpopulation of $\mathrm{CD}^{+}{ }^{+} \mathrm{T}$ cells as circulating 'memory' cells and possibly enhanced conversion of memory cells back into functional CTL upon re-exposure to tumor antigens. However, a population of CD4 ${ }^{+} \mathrm{CD} 25^{+}$Treg cells is capable of downregulating the action of CTL. These Treg cells may reside within the tumor microenvironment. The role of tumor-induced inflammation or recruitment of CD4 ${ }^{+} \mathrm{T}$ cells from the circulation in generating Treg cells is unclear. Regardless, TIL may induce both CTL and Treg cells, making assessment of TIL a critical clinical issue.

cells expressing only class I MHC molecules, not class II molecules, thereby limiting direct recognition by the $\mathrm{CD}^{+}{ }^{+}$T cells. Moreover, the predominant effector mechanism in tumor immunity is direct lysis of tumor cells by the MHC class I recognizing CD8 ${ }^{+}$CTL. The role of CD4 ${ }^{+} \mathrm{T}$ cells, in antitumor responses is often to aid in the activation of $\mathrm{CD}^{+} \mathrm{T}$ cells, leading to the destruction of the tumor by $\mathrm{CD}^{+}$CTL. The CD4 ${ }^{+}$T-cell help of the CD8 ${ }^{+}$CTLs in tumor immunity can be divided into three phases: early induction, effector maintence, and memory.

\section{CD4 ${ }^{+} \mathbf{T}$ cells help CTL induction}

It has been debated for decades if $\mathrm{CD}^{+}{ }^{+} \mathrm{T}$ cells are required for the priming of CTL. Accumulating evidence has indicated that for the induction of tumor-specific CD8 ${ }^{+}$T-cell responses, cross-presentation of antigens that have been captured by professional antigen-presenting cells (APCs) such as DCs plays a dominant role. ${ }^{85-89} \mathrm{CD} 4{ }^{+}$T-cell help has been hinted to be essential for such crosspriming in the induction of CTL immunity. This requirement for CD4 help is believed at least in part to activate APCs, ${ }^{90}$ which in turn express costimu- latory molecules such as ICAM-1, ${ }^{91}$ CD80, and CD86, ${ }^{92}$ or to secrete cytokines including interleukin (IL)-12. ${ }^{92,93}$ These factors are essential for better $\mathrm{CD8}^{+}$T-cell activation. Most T-cell help for CTL priming is dependent on the interaction between CD40 ligand (CD40L) expressed by CD4 ${ }^{+} \mathrm{T}$ cells and CD40 on APC. ${ }^{94-97}$ The CD40-CD40L interaction has also been proven to be important in the generation of protective T-cell-mediated tumor immunity. ${ }^{98,99}$ The requirement for $\mathrm{CD} 4{ }^{+} \mathrm{T}$ cells to 'license' APC for the priming of CTL helps explain some scenarios in which the induction of CTL can be achieved in the absence of $\mathrm{CD} 4^{+} \mathrm{T}$ cells. The typical CTL priming that is independent of $\mathrm{CD} 4^{+} \mathrm{T}$ cells is via the direct activation of DCs by virus that provides the optimal inflammatory signal to activate DCs, ${ }^{100}$ which can subsequently prime antigen-specific CTL responses in the absence of CD4 ${ }^{+}$T cells. ${ }^{101}$ CD4-independent CTL induction via activated DC is further demonstrated by data showing CD40-mediated activation with soluble ligand, or activating antibodies which 'license' DC for cross-priming in the absence of $\mathrm{CD}^{+}{ }^{+}$T cells..$^{98,99}$

However, these observations have not been confirmed in all experimental models. One study has shown that injection of MHC class I-deficient tumor 
cells into MHC class II knockout mice resulted in the induction of tumor cell-specific CTL responses, ${ }^{102}$ demonstrating that cross-priming can occur even in the absence of $\mathrm{CD} 4{ }^{+} \mathrm{T}$ cells, albeit with decreased efficiency. Hence, it is still possible that the requirement for CD4 help was bypassed in this model because DCs were activated by cellular components released during tumor cell apoptosis, which can serve as adjuvants. ${ }^{103}$

Other evidence seems to suggest that high levels of antigen can bypass the requirement for CD4 help in CTL induction. For example, RMA-S cells loaded with an MHC Class I-restricted peptide can induce CTL responses in vitro. The observed in vitro CTL priming was independent of $\mathrm{CD} 4^{+}$T cells or MHC class II-expressing cells, but was dependent upon the level of MHC class I expression on the RMA-S cells. $^{104}$ A high expression level of MHC class I peptide complexes on the peptide-presenting cells was the decisive requirement for the induction of CD4 ${ }^{+}$T-cell-independent CTL response in this model. This hypothesis would explain other observations in the vaccination experiment using MHC Class I-restricted peptides emulsified in noninflammatory incomplete Freund's adjuvant (IFA), whereby robust CTL function was induced in mice depleted of CD4 ${ }^{+}$T cells. ${ }^{105}$

Even with high level of antigen provided for CTL priming, other conditions may be required for CTL induction in the absence of CD4 help. We have shown that CD4 help is dispensable for crosspriming of CTL when intact draining lymph nodes are available ${ }^{88}$ However, in the absence of draining lymphoid tissue, this additional 'help' becomes essential for the proliferation of naïve $\mathrm{CD}^{+} \mathrm{T}$ cells. ${ }^{88}$

Other observations appropriately illustrate that the $\mathrm{CD} 4^{+}$help even in the presence of activated DCs cannot be altogether excluded or ignored, suggesting that $\mathrm{CD}^{+} \mathrm{T}$ cells may play roles other than 'licensing' DCs in CTL induction. For example, in experiments utilizing vaccinations with OVA-transduced CD40-activated DCs, only in the presence of $\mathrm{CD} 4^{+} \mathrm{T}$ cells was there protection against formation of ovalbumin (OVA)-expressing tumors. ${ }^{106}$ Furthermore, in some studies, vaccination with transduced DCs or DCs pulsed with peptides, tumor lysates, or tumor cell-derived exosomes has been shown to be at least partially CD4 ${ }^{+}$T cell-dependent, although it is possible that DCs were not properly activated prior to injection. ${ }^{107-110}$

In summary, the available data suggest that $\mathrm{CD} 4^{+}$ $\mathrm{T}$ cells are generally required for CTL priming when DCs are not activated through another mechanism. However, other conditions, such as the level of antigen provided or the integrity of draining lymphoid tissues, may also impact on the requirement for CD4 help. Nevertheless, CD4 ${ }^{+}$T-cell help has been considered essential for the induction of CTL responses against tumors in most cases. Given the noninflammatory condition of the majority of cancers in addition to the unavailability of tumor antigens for cross-presentation, ${ }^{89} \mathrm{DCs}$ require activation by $\mathrm{CD} 4^{+} \mathrm{T}$ cells before they can induce the full activation and differentiation of naïve $\mathrm{CD} 8^{+} \mathrm{T}$ cells into CTLs.

\section{$\mathrm{CD}^{+} \mathrm{T}$ cells help maintain a CTL response}

While the necessity of helper CD4 ${ }^{+} \mathrm{T}$ cells in the induction of CTL remains a controversy, it is generally accepted that CD4 ${ }^{+} \mathrm{T}$ cells are critical for the maintenance of CTL in both virally directed and tumor-specific immune responses. ${ }^{111-114}$ As clearly demonstrated in human cytomegalovirus (CMV) infection, the survival of adoptively transferred anti-CMV CTLs is dependent on the presence of CMV-specific $\mathrm{CD}^{+}{ }^{+} \mathrm{T}$ cells persisting in the host. ${ }^{115}$ For the host to perpetually sustain an effector CTL function to counter a persisting virus infection, help from CD4 ${ }^{+} \mathrm{T}$ cells may be required either through cytokine secretion or stimulation that is independent of DC help. In certain reports, the need for helper CD4 ${ }^{+} \mathrm{T}$ cells can be replaced by exogenously provided IL-2, ${ }^{116-118}$ suggesting that the requirement for $\mathrm{CD}_{4}{ }^{+} \mathrm{T}$ cells may simply be to supplement $\mathrm{CD}^{+} \mathrm{T}$ cells with IL-2, a cytokine traditionally thought to be essential for promoting growth and proliferation of $\mathrm{T}$ cells. Whether IL-2 is the primary mechanism or a byproduct utilized by $\mathrm{CD}^{+}$to provide help for the maintenance of CTL remains to be determined. However, the contribution of $\mathrm{CD}^{+}$help in sustaining a tumorspecific CTL response is unequivocally recognized as an important means to an end. There is no shortage of corroborating data from therapeutic vaccination and adoptive transfer studies that implicate $\mathrm{CD}^{+}$help in sustaining viable CTL function.

In some murine models, while tumor growth was prevented by vaccinations with peptide-pulsed DCmediated CTL induction, the same therapeutic immunization against an established tumor (a scenario mimicking the chronic persistence of antigen) required $\mathrm{CD}^{+}{ }^{+}$T-cell help. ${ }^{114}$ Similarly, while adoptive transfer of tumor-specific CTLs prevented tumor formation in $\mathrm{CD} 4{ }^{+} \mathrm{T}$ cells depleted or MHC class II knockout mice, systemic metastases (a condition that may require persistence of effector CTLs) could not be cured unless the hosts bear CD4 ${ }^{+}$T cells. ${ }^{119}$ Thus, as the tumor matures, CD4 ${ }^{+}$ help becomes vital to the persistence of the effector response. Published reports on clinical trials of adoptive immunotherapy further support this concept. ${ }^{55}$ Cotransfer of CD4 ${ }^{+}$T cells with CD8 ${ }^{+}$T cells expanded from autologous tumor-infiltrating T cells prolonged the survival of the adoptively transferred T cells. ${ }^{55}$ Taken together, it is evident that the longevity of a tumor-specific CTL response is enhanced by the presence of $\mathrm{CD} 4^{+} \mathrm{T}$ cells. 


\section{Role of CD4 ${ }^{+} \mathrm{T}$ cells in the induction and maintenance of $\mathrm{CDB}^{+} \mathrm{T}$-cell memory responses}

After the clearance of antigen the majority of effector CTLs undergo apoptosis, while a minor portion convert into lymphocytes with a memory phenotype. Thus, upon a second antigen encounter, CTL response propagates with alacrity and potency to provide the host with 'anamnestic' protection. It is generally accepted that memory cells persist in circulation subsequent to an effector response. However, the role of $\mathrm{CD} 4^{+} \mathrm{T}$ cells in the induction and maintenance of memory CTLs has been controversial. While recent publications seem to have reached a consensus that CD4 ${ }^{+} \mathrm{T}$ cells are indispensable for an intact CTL memory response, ${ }^{120-124}$ several studies have suggested that $\mathrm{CD}^{+}{ }^{+} \mathrm{T}$ cells are required in the primary antigenic encounter in order to 'program' the $\mathrm{CD}^{+}{ }^{+} \mathrm{T}$ cells to differentiate into long-lived, functional memory cells. ${ }^{120,121}$ Others have argued that $\mathrm{CD} 4^{+} \mathrm{T}$ cells are required after antigen is eliminated to maintain the number or normal functions of $\mathrm{CD}^{+}$memory T cells. ${ }^{123,124}$

In regard to achieving an anamnestic CTL response, one earlier study reported a $\mathrm{CD} 4^{+} \mathrm{T}$ - and B-cell-independent persistence of memory H-Yspecific CTLs. ${ }^{125}$ Two other groups also found that virus-specific peptide-tetramer-positive memory cells persisted in CD4 or MHC class II knockout mice using viral infection models. ${ }^{100,126}$ However, despite the clear presence of virus-specific CD8 ${ }^{+}$ memory $\mathrm{T}$ cells, both groups were unable to revert memory T cells into effector T cells in the absence of $\mathrm{CD}^{+}{ }^{+}$T cells. ${ }^{100,126}$ In other words, the memory phenotype $\mathrm{CD}^{+}{ }^{+} \mathrm{T}$ cells were nonfunctional. Similar results were obtained in the previously described mouse H-Y model, whereby exogenous cytokine addition was required to revert memory cells back into CTLs in the absence of CD4 ${ }^{+}$T cells. $^{125}$ These earlier findings suggest that $\mathrm{CD}^{+} \mathrm{T}$ cells were essential for the conversion of memory CTLs into effector CTLs upon secondary antigen encounter. Other groups have expanded on the aforementioned studies by utilizing adoptive transfer experiments to emphasize the necessity of CD4 ${ }^{+}$in sustaining the memory cells in the circulation. They complemented earlier studies with MHC class II knockout mice in adoptive transfer of memory $\mathrm{T}$ cells, by illustrating that, in the absence of $\mathrm{CD} 4^{+}$help, reactivation into effector CTLs could not occur. ${ }^{119}$ While these earlier studies did not address whether $\mathrm{CD} 4^{+} \mathrm{T}$ cells were required in the priming phase of CLT to 'program' them to later develop into long-lived functional memory cells, recent studies by Bevan's group revealed that $\mathrm{CD} 4{ }^{+} \mathrm{T}$ cells are not required during the priming of CTL, but only are required at a later stage for the maintenance of memory CD8 ${ }^{+}$ T cells. ${ }^{123}$

However, two recent publications by Shedlock et $a l^{121}$ and Janssen et $a l^{120}$ supported the idea that
$\mathrm{CD}^{+}{ }^{+} \mathrm{T}$ cells are only essential during the primary antigen encounter to 'program' the $\mathrm{CD}^{+}{ }^{+} \mathrm{T}$ cells to differentiate into long-lived, functional memory cells. They show that adoptively transferred CTLs can survive and function properly in an environment without CD4 ${ }^{+} \mathrm{T}$ cells after being primed in their presence. ${ }^{120,121}$ In addition, $\mathrm{CD} 4{ }^{+} \mathrm{T}$ cells were not required for the secondary activation of CTLs. Taken together, the data available suggest a general requirement for CD4 help to generate a healthy CD8 memory. However, the stage at which CD8 T-cell responses require CD4 help and the nature of such help remain unresolved.

\section{Th1 vs Th2 responses for anti-tumor immunity}

CD4 ${ }^{+}$T-cell responses can be divided into different types depending upon their cytokine profile. ${ }^{127}$ The defined Th1 cells are characterized especially by the production of interferon (IFN)- $\gamma$, whereas Th2 cells produce IL-4, IL-5 and other cytokines. The balance between Th1 and Th2 cytokines has definite influence on the outcome of various immune responses, as Th1 preferentially induces cellular immunity and Th2 tends to elicit humoral immunity. ${ }^{128}$ The cytokine IFN- $\gamma$ impacts positively on antigen processing and presentation because MHC class I and II-and the expression of several other molecules such as transporter associated with antigen processing (TAP) and proteasome components-are under the control of this cytokine. ${ }^{129}$ Therefore, the Th1 response is generally correlated with a better cellular and CTL response. Since a cellular immune response is preferable for tumor destruction, a Th1 response has been proposed to be beneficial for antitumor immunity. Several reports have supported this idea and demonstrated the parallelism between the generation of a Th1 response and a stronger antitumor immunity. ${ }^{130-134}$ A Th1 response has even been shown to be essential for antitumor immunity, and Th2 cytokines downregulate antitumor immunity in some reports. ${ }^{134-136}$ The concept of immune deviation, namely, a shift from a Th1 to a Th2 cytokine profile, has been hinted to be one of the major contributors to the failure of T-cell-mediated immunity against tumors. Indeed, immune deviation to Th2 cytokine production has been reported in progressive cancer patients. ${ }^{137}$ On the contrary, an immunizationevoked Th2 to Th1 change was shown to induce tumor rejection in a murine tumor model. ${ }^{138}$ Additionally, Th2 cytokines have been shown to promote tumor growth in several experimental models. ${ }^{138}$

However, as in most immunological situations, one can never irrevocably conclude one way over another. There are plenty of data supporting the opposite: Th2 cytokines have been shown to be helpful for cancer gene therapy, ${ }^{139,140}$ and tumor- 
specific Th2 clones have been demonstrated to exhibit strong antitumor activity in vivo. ${ }^{141-144}$ The mechanisms of how Th2 helper $\mathrm{T}$ cells destroy tumors are not yet established, but there is some evidence to suggest that the antitumor effect is mediated through the activation of innate immune cells such as eosinophils and macrophages by Th2 $\mathrm{CD}^{+} \mathrm{T}$ cells, which in turn secrete superoxide and nitric oxide. ${ }^{145}$ Although an effective antitumor immunity would be preferentially mediated through a Th1 response resulting in a direct killing by CTL, the results published up to this point seems to be directed towards a cooperative balance between the Th1 and Th2.

\section{$\mathrm{CD}^{+}$regulatory $\mathrm{T}$ cells within the tumor environment}

Succinctly stated, the immune system is constantly working to find a balance between Th1 and Th2, activation and apoptosis, and proinflammatory and anti-inflammatory conditions. It has recently come to light that during tumor progression the tumor microenvironment becomes host to such a balancing event, specifically the balance between the effector and the regulatory response. Although not much is known regarding T-cell regulatory function pertaining to the tumor immunity, there is some evidence to suggest that the subtype of $\mathrm{T}$ cells responsible for 'regulating' the effector immune response within the tumor site is similar to the now well-characterized regulatory $\mathrm{CD}^{+}{ }^{+} \mathrm{T}$ cells involved in autoimmunity. ${ }^{16,18,75-79}$

\section{Existence of different types of CD4 ${ }^{+}$ regulatory $\mathrm{T}$ cells in vivo}

During the past decades there has been much speculation and some evidence suggesting the existence of suppressor T cells, but these cells were only recently identified phenotypically. A major advance resulted from the discovery by Sakaguchi and colleagues, and later confirmed by others, that depletion of this small subset of $\mathrm{CD}^{+} \mathrm{T}$ cells, distinguished from $\mathrm{CD}^{+}$helper $\mathrm{T}$ cells by the expression of high levels of CD25 in naïve mice, could induce organ-specific autoimmunity. Adoptive transfer of CD4 ${ }^{+} \mathrm{CD} 25^{+} \mathrm{T}$ cells could prevent the development of organ-specific autoimmunity. ${ }^{146-}$ 148 These data established the regulatory nature of these cells, now defined as naturally occurring $\mathrm{CD}^{+}{ }^{+} \mathrm{CD} 25^{+}$T regulatory cells. This subset of cells has been established to be a powerful regulator of Tcell responses in organ-specific autoimmunity and chronic infections. ${ }^{149-153}$ However, it is becoming increasingly clear that, in many situations, $\mathrm{CD} 4{ }^{+} \mathrm{CD} 25^{-} \mathrm{T}$ cells are as effective as $\mathrm{CD} 4{ }^{+} \mathrm{CD} 25^{+}$ $\mathrm{T}$ cells in controlling T-cell-mediated disease. ${ }^{154-156}$ There are other subsets of CD4 ${ }^{+} \mathrm{T}$ cells that exhibit regulatory phenotypes, including $\mathrm{CD} 4{ }^{+} \mathrm{CD} 45 \mathrm{Rb}^{\text {low }}$ suppressor cells that secrete large quantities of IL-10 and IL-4 (termed Tr1 cells) and CD4 ${ }^{+}$suppressor T cells that secrete large quantities of transforming growth factor (TGF)- $\beta$ (termed Th3 cells). ${ }^{157,158}$ The immune-regulatory potential and functional significance of these cytokine-secreting $\mathrm{CD} 4^{+} \mathrm{T}$ cells are supported by the findings that TGF- $\beta$-deficient mice develop autoimmune disease ${ }^{159}$ and administration of neutralizing antibodies to IL- 4 or TGF- $\beta$ abrogates the in vivo prevention of autoimmunity or toleranceinducing activity of CD4 ${ }^{+}$T cells in tumor models and some autoimmunity models. ${ }^{18,160,161}$ It remains to be determined, however, to what extent these subtypes of $\mathrm{CD}^{+}$cells diverge from naturally occurring $\mathrm{CD} 4{ }^{+} \mathrm{CD} 25^{+} \mathrm{T}$ cells in regulatory function and significance.

\section{Markers to identify CD4 ${ }^{+}$regulatory T cells in vivo}

There are no known cell surface molecules that uniquely distinguish the $\mathrm{CD}^{+}$regulatory $\mathrm{T}$ cells (Treg) from conventional activated CD4 ${ }^{+}$cells. For example, the CD25 molecule, which is the $\alpha$-chain of the IL-2 receptor, is expressed on all peripheral antigen-reactive CD4 ${ }^{+} \mathrm{T}$ cells from one to several days following antigen activation. Moreover, many of the other cell-surface molecules in addition to CD25, including the tumor necrosis factor (TNF)family member glucocorticoid-induced TNF receptor (GITR) and cytotoxic T-lymphocyte antigen-4 (CTLA4) ${ }^{162,163}$ that seem to distinguish $\mathrm{CD} 4{ }^{+} \mathrm{CD} 25^{+}$ from $\mathrm{CD} 4{ }^{+} \mathrm{CD} 25^{-}$effector cells, are upregulated on $\mathrm{CD} 4{ }^{+} \mathrm{CD} 25^{-} \mathrm{T}$ cells following antigen activation. In this regard, it is of great interest that a recently cloned transcription factor, termed Foxp3, a member of the forkhead family of DNA-binding transcription factors, is not expressed in naïve $\mathrm{CD} 4{ }^{+} \mathrm{CD} 25^{-}$cells, but is highly expressed in the naturally occurring $\mathrm{CD} 4{ }^{+} \mathrm{CD} 25^{+}$regulatory cells. More importantly, mutational defects in the Foxp3 gene result in the fatal autoimmune and inflammatory disorder of the scurfy mouse and in the clinical and molecular features of the immunodysregulation, polyendocrinopathy, enteropathy, and X-linked syndrome (IPEX syndrome) in humans. ${ }^{164-166}$ In Foxp3-overexpressing mice, both $\mathrm{CD} 4{ }^{+} \mathrm{CD} 25^{-}$and $\mathrm{CD} 4^{-} \mathrm{CD} 8^{+} \mathrm{T}$ cells show suppressive activity, which suggests that expression of Foxp3 is linked to suppressor functions. ${ }^{167-169}$ Taken together, these data strongly support the idea that Foxp3 may uniquely define the subset of $\mathrm{CD}^{+}$Treg in mice ${ }^{167-169}$ and humans. ${ }^{170}$ However, the recent findings that Foxp3 can be expressed in $\mathrm{CD} 4{ }^{+} \mathrm{CD} 25^{-}$cells following activation and is also expressed in activated CD8 ${ }^{+} \mathrm{T}$ cells suggest that Foxp3 is linked to functional suppression, but is not necessarily a specific lineage marker. ${ }^{170-173}$ Whether a specific lineage marker even exists for these $\mathrm{CD} 4{ }^{+}$regulatory cells awaits to be determined, but what can be concluded with 
little doubt is that a subset of $\mathrm{CD}^{+}{ }^{+} \mathrm{T}$ cells exist that regulate an inflammatory immune response to cancer.

\section{Tumor-induced CD4 ${ }^{+}$Treg}

Cancers generally develop over a long period of time. In addition, the major pathophysiologic characteristics of malignant cancer, invasion across natural tissue barriers and metastasis, are often associated with the disruption of normal tissue architecture leading to the initiation of inflammatory responses. In this regard, cancers can very much resembled to a chronic inflammatory response. In view of this, one can speculate that the anti-inflammatory mechanisms that are turned on at the beginning of invasion coupled with the internal mechanisms controlled by malignant cells to produce cytokines like TGF- $\beta$ set off a regulatory reaction, which may inhibit antitumor immunity. Given such events, the loss of regulatory function by depletion of tumor-induced $\mathrm{CD}^{+}$Treg may enhance the effector response, resulting in tumor rejection.

Recent findings specifically attest to possible negative regulatory roles by $\mathrm{CD}^{+} \mathrm{T}$ cells within the tumor environment. In some spontaneous tumor models, the presence of $\mathrm{CD}^{+}{ }^{+} \mathrm{T}$ cells seems to promote cancer development instead of inhibiting it. ${ }^{174}$ One study by Schreiber's group has shown that active immunization with antigen-specific $\mathrm{CD}^{+}{ }^{+} \mathrm{T}$ cells in cancer-prone mice carrying a germline mutant ras oncogene resulted in immune responses that fail to eradicate mutant oncogene-expressing tumor cells, and instead induced a remarkable enhancement of tumor growth. ${ }^{175}$ Similarly, the studies by North ${ }^{73,74}$ have shown that suppression by $\mathrm{CD}^{+}{ }^{+} \mathrm{T}$ cells led to the progressive growth of an immunogenic tumor and intravenous depletion of these cells reversed the suppression and elicited $\mathrm{CD}^{+}$T-cell-mediated antitumor immunity. ${ }^{72}$ While the presence of $\mathrm{CD}^{+} \mathrm{T}$ cells in some models has been shown to be deleterious to the onset of tumor immunity, the necessity of $\mathrm{CD}^{+}$T-cell help in mounting an effector immune response cannot be negated. In some studies, the depleting antibody given during the early stages of tumor growth was damaging to the generation of an immune response against the tumor, especially if T-cell help was obligatory. ${ }^{19,21}$ These obsevations strongly suggest the existence of functionally distinct $\mathrm{CD} 4{ }^{+}$T-cell subsets.

\section{CD4 ${ }^{+}$CD25 $^{+}$Treg in mice and humans}

The above studies have suggested that CD4 ${ }^{+} \mathrm{CD} 25^{+}$ suppressor cells are relevant to tumor immunology, albeit more detrimental than favorable for the host. Most studies up to recent times have utilized depletion of the entire $\mathrm{CD}^{+}{ }^{+}$population, resulting in enhancement of immunity against tumors via the depletion of the suppressive $\mathrm{CD}^{+}{ }^{+} \mathrm{CD} 25^{+}$T-cell population. In vivo experiments in several murine tumor models demonstrate that more specific depletion of $\mathrm{CD}^{+}{ }^{+} \mathrm{CD} 25^{+} \mathrm{T}$ cells by anti-CD25 antibody treatment prior to tumor challenge significantly enhances the efficacy of vaccine-induced antitumor immunity. ${ }^{20-29}$ Another study revealed that splenic cells depleted of $\mathrm{CD}^{+}{ }^{+} \mathrm{CD} 25^{+} \mathrm{T}$ cells can mediate tumor regression, presumably through promoting autoreactivity because autoimmune diseases were also induced. ${ }^{23}$ These studies suggest that Treg may inhibit initial priming of $\mathrm{CD}^{+} \mathrm{T}$ cells, some of which recognize tumor antigens. One study demonstrated more clearly that the $\mathrm{CD} 4{ }^{+} \mathrm{CD} 25^{+} \mathrm{T}$ cells prevented priming of CTL, as depletion of CD25 ${ }^{+} \mathrm{T}$ cells had to be performed within the first 2 days after tumor inoculation, suggesting that suppression was ineffective once the priming was initiated. ${ }^{24}$ It was also shown that elimination of these Treg, despite causing increased autoreactivity in some cases, could increase immune responses to tumors such as melanomas overexpressing self-antigens. ${ }^{21-23,26}$ Even when the host bears a poorly immunogenic cancer, concomitant immunity can be rescued by systemic depletion of the $\mathrm{CD} 4{ }^{+} \mathrm{CD} 25^{+}$regulatory T-cell subset. ${ }^{19}$ These observations in the tumor models are consistent with the features that have been defined for CD4 ${ }^{+} \mathrm{CD}_{25}{ }^{+}$Treg in other disease models.

It has been demonstrated that the equivalent of $\mathrm{CD} 4{ }^{+} \mathrm{CD}_{25}{ }^{+}$Treg identified in mice also exists in humans. These cells, CD $4{ }^{+} \mathrm{CD}^{2} 5^{+} \mathrm{CD} 45 \mathrm{RO}{ }^{+} \mathrm{T}$ cells, represent about $6 \%$ of $\mathrm{CD}^{+}{ }^{+} \mathrm{T}$ cells and are present in the blood of healthy human adults. ${ }^{76}$ Prevalence of Treg is increased in peripheral blood and the tumor microenvironment of patients with pancreas or breast adenocarcinoma. ${ }^{77}$ The $\mathrm{CD} 4^{+} \mathrm{CD} 25^{+}$ $\mathrm{T}$ cells possessing regulatory properties have also been reported to be among the tumor-infiltrating $\mathrm{T}$ cells in different types of human lung, ovarian, pancreas, breast and gastrointestinal cancers, and lymphoma. ${ }^{78,79,176,177}$ Antigen-specific activation and cell-cell contact were required for these clones of Treg cells to exert suppressive activity on $\mathrm{CD} 4^{+}$ effector cells. The presence of $\mathrm{CD}^{+}{ }^{+}$Treg cells at tumor sites suggests that they could have a profound effect on the inhibition of T-cell effector responses against some human cancers. ${ }^{16,18,75}$

\section{Immune suppression occurrs inside tumor tissues}

It is possible that different subsets of CD4 ${ }^{+} \mathrm{T}$ cells, either by providing 'help' or 'regulation', predominate at various stages of tumor progression. A recent study by our group ${ }^{18}$ has shown that suppression of immunity against tumors mainly occurs in the effector phase at the tumor site and depletion of the Treg at the late-stage of tumor progression did not 
mitigate the possible T-helper function. We found that a highly antigenic tumor that expresses a strong antigen on the surface, yet fails to regress in the host, induced an accumulation of $\mathrm{CD} 4^{+}$Treg within the tumor microenvironment. With tumor persistence, there was inhibition of $\mathrm{CD}^{+}$T-cell function. In this model, local intratumoral depletion of these $\mathrm{CD}^{+}{ }^{+}$Treg unmasked the immunogenicity of tumor and reversed the CTL tolerization, leading to the rapid rejection of well-established tumors. From this study, we propose that $\mathrm{CD}^{+}$cells predominantly play an enhancing helper role during the initial stages of tumor progression, but once tumors become chronically persistent, the increased accumulation of $\mathrm{CD}^{+}{ }^{+}$Treg inhibits $\mathrm{CD}^{+}$cell function and mask the immunogenicity of tumor. In fact, depletion of Treg unveils the immunogenicity of tumor cells and provides long-term protection against re-challenge of even poorly immunogenic parental tumor cells. This result suggests that the depletion of Treg promoted immunity against previously poorly immunogenic tumor antigens and expanded the tumor-reactive $\mathrm{CD}^{+}$T-cell repertoire. Our study revealed that the population of tumor-infiltrating cells is skewed to favor regulatory $\mathrm{CD}^{+}{ }^{+} \mathrm{T}$ cells over the helper $\mathrm{CD}^{+}{ }^{+} \mathrm{T}$ cells within the tumor tissue, especially as tumor progresses and becomes established in the host.

\section{Origins of tumor-induced CD4 ${ }^{+}$Treg}

It is not clear thus far whether $\mathrm{CD} 4{ }^{+} \mathrm{CD} 25^{+} \mathrm{T}$ cells inhibiting antitumor immunity in mice and humans are naturally occurring Treg or are generated in the periphery. It is possible that the tumor microenvironment preferentially recruits naturally occurring $\mathrm{CD} 4{ }^{+} \mathrm{CD} 25^{+} \mathrm{T}$ cells. One study published recently suggested that the chemokine CCL22, abundantly expressed in ovarian cancer tissues and tumor ascites cells, preferentially attracts the $\mathrm{CD} 4{ }^{+} \mathrm{CD} 25^{+}$ $\mathrm{T}$ cells identified in the ovarian cancers. ${ }^{16}$ These cells were positive for the transcriptional factor Foxp-3 and exhibited regulatory function similar to the naturally occurring $\mathrm{CD} 4^{+} \mathrm{CD} 25^{+} \mathrm{T}$ cells. It is not yet clear whether these tumor-infiltrating Treg can be defined as the counterpart of the naturally occurring $\mathrm{CD}^{+}{ }^{+} \mathrm{CD} 25^{+} \mathrm{T}$ cells in the mouse. Another possibility is that the tumor microenvironment converts $\mathrm{CD} 4{ }^{+} \mathrm{T}$ cells to $\mathrm{CD} 4{ }^{+} \mathrm{CD} 25^{+}$Treg or expands naturally occurring $\mathrm{CD} 4{ }^{+} \mathrm{CD} 25^{+} \mathrm{T}$ cells. There is evidence to indicate that tumor-specific $\mathrm{CD}^{+}{ }^{+} \mathrm{T}$ cells change their phenotype from effectors to suppressors during cancer progression. ${ }^{178}$ Conversion from effector cells coincided with a substantial reduction in the antigen expression level, resulting in tumor persistence that ultimately led to T-cell tolerance. The authors have evidence to suggest further that these antigen-specific $\mathrm{T}$ cells became $\mathrm{CD} 4{ }^{+} \mathrm{CD} 25^{+}$Treg. ${ }^{178}$
It may therefore be that the processes of immunosurveillance and tumor editing coexist with a process in which the functional tumor-specific T-cell repertoire is also edited by the tumor environment, to the ultimate benefit of tumor progression. Besides anti-inflammatory cytokines, the $\mathrm{CD} 4{ }^{+} \mathrm{CD} 25^{+}$Treg inside the tumor may suppress antitumor immunity via other mechanisms. For example, these 'Tregs' may inhibit the immune response through their ability to control T-cell numbers because they have been shown to regulate T-cell proliferation in vitro. ${ }^{152,153}$ Whether the regulatory cells that accumulate in the tumor site are ones that naturally exist in the host, or whether they initially arrive as helper $\mathrm{CD}^{+}{ }^{+} \mathrm{T}$ cells, but convert to regulatory cells by encountering the suppressive tumor environment is not altogether clear. It would be beneficial to better characterize the nature of $\mathrm{CD} 4^{+} \mathrm{T}$ cells isolated from or present in the tumor tissues by surface markers and cytokine profiles, in order to utilize the CD4 ${ }^{+}$helper T cells instead of $\mathrm{CD}^{+}{ }^{+}$Treg for adoptive transfer immunotherapy and potentially improve the prognosis of cancer patients.

\section{Targeting tumor tissues to recruit and train $T$ cells}

Tumors often form a barrier that limits T-cell infiltration and reduces drainage of tumor antigens to lymph nodes. Since positive roles are played by $\mathrm{CD}^{+}{ }^{+} \mathrm{T}$ cells and CD4 ${ }^{+}$helper T cells in antitumor immunity, it is reasonable to speculate that infiltration of $\mathrm{T}$ lymphocytes and initiation of antitumor immune responses inside tumor tissue at an early phase are highly favorable. Specifically, it could increase the T-cell repertoire and provide more antigens to stimulate T cells inside tumor, and could therefore be a strategy for cancer immunotherapy. Several cytokines or chemokines have been used to attract and activate $\mathrm{T}$ cells at tumor sites. In this section, we will focus on our recent finding that stimulation of lymphotoxin (LT) $\beta$ receptor (LT $\beta$ R) inside tumor tissues promotes strong infiltration of immune cells, leading to tumor rejection.

LT $\beta$ R plays an important role in the formation of lymphoid structures. ${ }^{179-181}$ LT $\beta$ R is activated by two members of the TNF family, membrane LT $\alpha \beta$ and the LT-related inducible ligand that competes for glycoprotein $\mathrm{D}$ binding to herpesvirus entry mediator on $\mathrm{T}$ cells (LIGHT). ${ }^{182}$ Signaling via LT $\beta \mathrm{R}$ regulates the expression of chemokines and adhesion molecules within secondary lymphoid organs. For example, such chemokines and adhesion molecules control the migration and positioning of DCs and lymphocytes in the spleen. ${ }^{183,184}$ Therefore, it is possible that enhanced LT $\beta$ R signaling inside tumor tissues may promote the formation of lymphoid-like structures for direct T-cell sequestration. TNF receptor (TNFR) signaling may also play a similar, 
but less effective role in regulating chemokine expression. ${ }^{184}$ However, TNFR signaling may have a more toxic effect, as has been seen in other systemic TNF treatments without extra costimulation. ${ }^{185}$ Soluble LT $\alpha$ can signal through the TNFR, resulting in the upregulation of chemokines. To avoid such a toxic effect, recombinant LT $\alpha$ has been conjugated with antibody targeted specifically to the tumor tissues, resulting in an effective antitumor immune response associated with the induction of peripheral lymphoid-like tissue. ${ }^{186}$ However, LT $\alpha$ lacks a costimulation function, which would result in a less effective activation of recruited naïve $\mathrm{T}$ cells in the lymphoid-like structure inside tumor tissues.

LIGHT is a ligand for LT $\beta$ R and herpes virus entry mediator (HVEM). ${ }^{182,187}$ LIGHT is predominantly expressed in lymphoid tissues, especially on the surface of activated DCs and T cells. LIGHT is a strong costimulatory molecule. ${ }^{182,188,189}$ Our data indicate that the interactions between LIGHT and LT $\beta$ R restore lymphoid structures in the spleen of $\mathrm{LT} \alpha^{-1-}$ mice. In addition, upregulation of LIGHT causes T-cell activation and migration into nonlymphoid tissues and formation of lymphoid-like structures. ${ }^{190,191}$ Therefore, a LIGHT-mediated microenvironment inside a tumor could be effective in both recruiting and activating naïve $\mathrm{T}$ cells. The expression of LIGHT in the tumor environment induces a massive infiltration of naïve $\mathrm{T}$ lymphocytes that correlates with an upregulation of both chemokine production and expression of adhesion molecules. Activation and expansion of these infiltrating $\mathrm{T}$ cells leads to the rejection of established, highly progressive tumors at local and distal sites. ${ }^{192}$ Our study indicates that induction of T lymphocytes and initiation of antitumor immune responses inside the tumor tissue may be an effective strategy for cancer immunotherapy.

\section{Conclusion: incorporating two strategies to promote tumor regression}

The balance of antitumor effector T cells vs Treg may be critically important in determining the outcome of immune responses within tumors. Our recent study has demonstrated that rapid recruitment of naïve lymphocytes and expansion of CD8 ${ }^{+} \mathrm{T}$ cells inside tumors may be a way of creating a dominant proinflammatory environment, leading to tumor rejection at local and distal sites. ${ }^{192}$ We further demonstrated that the depletion of Treg inside the tumor is another efficient way of converting the local anti-inflammatory environment to a proinflammatory one. ${ }^{18}$ From a clinical-therapeutic point of the view, local treatment to eliminate Treg has certain critical advantages over systemic treatment. First, local treatment may avoid side effects induced by systemic depletion of CD4 ${ }^{+} \mathrm{T}$ cells, which may abrogate $\mathrm{T}$ helper-mediated protective immunity against pathogens. Second, treatment of the local tumor environment would not hinder effective priming of $\mathrm{CD}^{+} \mathrm{T}$ cell in lymphoid tissues by helper $\mathrm{CD}^{+}{ }^{+} \mathrm{T}$ cells, since depletion remains local. Third, the local treatment would be expected to be more effective if suppression of $\mathrm{CD} 4{ }^{+} \mathrm{CD} 25^{+}$Treg resides inside the tumor. $\mathrm{CD} 4{ }^{+} \mathrm{CD} 25^{+} \mathrm{T}$ cells have been shown to be present in a variety of human cancer tissues ${ }^{78,79,176,177}$ and these cells are negatively associated with the prognosis of the ovarian cancer patients in addition. ${ }^{16}$ Therefore, Treg within the tumor environment represent an attractive target, and their depletion may lead to improvements in the current immunotherapy protocol in the future clinical trials. Finally, intratumoral treatment would reduce the dose of depleting agent, for example, antibody, required. It is likely that a combination treatment which would rapidly expand the effector cells at the tumor site, while locally depleting the regulatory cells, could constitute a potent strategy for enhancing antitumor immunity and promote a clinically desirable outcome for cancer patients.

It is increasingly clear that some TILs may be friends, while others may be foes. An increase in TIL may not always be associated with a better prognosis. Accumulation of Treg inside tumor tissue both in animal models and in human patients suggests that an aberrant immune response can occur inside growing tumors. Strategies to effectively reverse the immunologically suppressive environment (eg, depleting Treg inside tumors) may be a new way to enhance the effectiveness of immune responses against tumors at local and distal sites.

Further laboratory investigation is critical for us to better understand the role of TIL. A hypothesis to be further tested is if cancer tissue contains few TIL, local treatment to increase TIL in tumor tissue, especially CTL, may be advantageous. On the other hand, depletion of $\mathrm{T}$ regulatory cells may be important for patients with cancer tissues containing abundant T regulatory cells. Pathologists of the future may play critical diagnostic roles in determining the type of TIL infiltrates, thereby providing both prognostic information as well as guidance in selecting an appropriate immunotherapeutic strategy for each patient.

\section{References}

1 Gross L. Intradermal immunization of $\mathrm{C} 3 \mathrm{H}$ mice against a sarcoma that originated in an animal of the same line. Cancer Res 1943;3:326-333.

2 Baldwin RW. Immunity to methylcholanthreneinduced tumours in inbred rats following atrophy and regression of the implanted tumours. Br J Cancer 1955;9:652-657.

3 Foley EJ. Antigenic properties of methylcholanthrene-induced tumors in mice of the strain of origin. Cancer Res 1953;13:835-837. 
4 Prehn RT, Main JM. Immunity to methylcholanthrene-induced sarcomas. J Natl Cancer Inst 1957;18: 769-778.

5 Boyse EA, Old LJ, Stockert E. Some further data on cytotoxic isoantibodies in the mouse. Ann NY Acad Sci 1962;99:574-587.

6 Globerson A, Feldman M. Antigenic specificity of benzo(a)pyrene-induced sarcomas. J Natl Cancer Inst 1964;32:1229-1243.

7 Klein G, Sjogren HO, Klein E, et al. Demonstration of resistance against methylcholanthrene-induced sarcomas in the primary autochthonous host. Cancer Res 1960;20:1561-1572.

8 Pardoll D. Does the immune system see tumors as foreign or self? Annu Rev Immunol 2003;21:807-839.

9 Dunn GP, Old LJ, Schreiber RD. The three Es of cancer immunoediting. Annu Rev Immunol 2004;22: 329-360.

10 Rosenberg SA. A new era for cancer immunotherapy based on the genes that encode cancer antigens. Immunity 1999;10:281-287.

11 Wick M, Dubey P, Koeppen H, et al. Antigenic cancer cells grow progressively in immune hosts without evidence for $\mathrm{T}$ cell exhaustion or systemic anergy. J Exp Med 1997;186:229-238.

12 Boon T, van der Bruggen P. Human tumor antigens recognized by T lymphocytes. J Exp Med 1996;183: $725-729$.

13 Rosenberg SA. Progress in the development of immunotherapy for the treatment of patients with cancer. J Intern Med 2001;250:462-475.

14 Clark Jr WH, Elder DE, Guerry DT, et al. Model predicting survival in stage I melanoma based on tumor progression. J Natl Cancer Inst 1989;81:1893-1904.

15 Clemente CG, Mihm Jr MC, Bufalino R, et al. Prognostic value of tumor infiltrating lymphocytes in the vertical growth phase of primary cutaneous melanoma. Cancer 1996;77:1303-1310.

16 Curiel TJ, Coukos G, Zou L, et al. Specific recruitment of regulatory $\mathrm{T}$ cells in ovarian carcinoma fosters immune privilege and predicts reduced survival. Nat Med 2004;10:942-949.

17 Zhang L, Conejo-Garcia JR, Katsaros D, et al. Intratumoral T cells, recurrence, and survival in epithelial ovarian cancer. N Engl J Med 2003;348:203-213.

$18 \mathrm{Yu} \mathrm{P}$, Lee Y, Liu W, et al. Intratumor depletion of CD4+ cells unmasks tumor immunogenicity leading to the rejection of late-stage tumors. J Exp Med 2005; 201:779-791.

19 Turk MJ, Guevara-Patino JA, Rizzuto GA, et al. Concomitant tumor immunity to a poorly immunogenic melanoma is prevented by regulatory $\mathrm{T}$ cells. J Exp Med 2004;200:771-782.

20 Tawara I, Take Y, Uenaka A, et al. Sequential involvement of two distinct CD4+ regulatory $\mathrm{T}$ cells during the course of transplantable tumor growth and protection from 3-methylcholanthrene-induced tumorigenesis by CD25-depletion. Jpn J Cancer Res 2002;93:911-916.

21 Sutmuller RP, van Duivenvoorde LM, van Elsas A, et al. Synergism of cytotoxic T lymphocyte-associated antigen 4 blockade and depletion of CD25(+) regulatory $\mathrm{T}$ cells in antitumor therapy reveals alternative pathways for suppression of autoreactive cytotoxic T lymphocyte responses. J Exp Med 2001;194:823-832.

22 Steitz J, Bruck J, Lenz J, et al. Depletion of CD25(+) CD4(+) T cells and treatment with tyrosinase-related protein 2-transduced dendritic cells enhance the interferon alpha-induced, CD8(+) T-cell-dependent immune defense of B16 melanoma. Cancer Res 2001; 61:8643-8646.

23 Shimizu J, Yamazaki S, Sakaguchi S. Induction of tumor immunity by removing CD25+CD4+ T cells: a common basis between tumor immunity and autoimmunity. J Immunol 1999;163:5211-5218.

24 Onizuka S, Tawara I, Shimizu J, et al. Tumor rejection by in vivo administration of anti-CD25 (interleukin-2 receptor alpha) monoclonal antibody. Cancer Res 1999;59:3128-3133.

$25 \mathrm{Li} \mathrm{J}, \mathrm{Hu} \mathrm{P}$, Khawli LA, et al. Complete regression of experimental solid tumors by combination LEC/ chTNT-3 immunotherapy and CD25(+) T-cell depletion. Cancer Res 2003;63:8384-8392.

26 Jones E, Dahm-Vicker M, Simon AK, et al. Depletion of CD25+ regulatory cells results in suppression of melanoma growth and induction of autoreactivity in mice. Cancer Immun 2002;2:1.

27 Golgher D, Jones E, Powrie F, et al. Depletion of CD25+ regulatory cells uncovers immune responses to shared murine tumor rejection antigens. Eur J Immunol 2002;32:3267-3275.

28 Casares N, Arribillaga L, Sarobe P, et al. CD4+/CD25+ regulatory cells inhibit activation of tumor-primed CD4+ T cells with IFN-gamma-dependent antiangiogenic activity, as well as long-lasting tumor immunity elicited by peptide vaccination. J Immunol 2003;171: 5931-5939.

29 Machiels JP, Reilly RT, Emens LA, et al. Cyclophosphamide, doxorubicin, and paclitaxel enhance the antitumor immune response of granulocyte/macrophage-colony stimulating factor-secreting whole-cell vaccines in HER-2/neu tolerized mice. Cancer Res 2001;61:3689-3697.

30 Marrogi AJ, Munshi A, Merogi AJ, et al. Study of tumor infiltrating lymphocytes and transforming growth factor-beta as prognostic factors in breast carcinoma. Int J Cancer 1997;74:492-501.

31 Naito Y, Saito K, Shiiba K, et al. CD8+ T cells infiltrated within cancer cell nests as a prognostic factor in human colorectal cancer. Cancer Res 1998; 58:3491-3494.

32 Schumacher K, Haensch W, Roefzaad C, et al. Prognostic significance of activated CD8(+) T cell infiltrations within esophageal carcinomas. Cancer Res 2001;61:3932-3936.

33 Saiki Y, Ohtani H, Naito Y, et al. Immunophenotypic characterization of Epstein-Barr virus-associated gastric carcinoma: massive infiltration by proliferating CD8+ T-lymphocytes. Lab Invest 1996;75:67-76.

34 Nakano O, Sato M, Naito Y, et al. Proliferative activity of intratumoral CD8(+) T-lymphocytes as a prognostic factor in human renal cell carcinoma: clinicopathologic demonstration of antitumor immunity. Cancer Res 2001;61:5132-5136.

35 Banner BF, Burnham JA, Bahnson RR, et al. Immunophenotypic markers in renal cell carcinoma. Mod Pathol 1990;3:129-134.

36 Kolbeck PC, Kaveggia FF, Johansson SL, et al. The relationships among tumor-infiltrating lymphocytes, histopathologic findings, and long-term clinical follow-up in renal cell carcinoma. Mod Pathol 1992;5: $420-425$.

37 Kowalczyk D, Skorupski W, Kwias Z, et al. Flow cytometric analysis of tumour-infiltrating lympho- 
cytes in patients with renal cell carcinoma. Br J Urol 1997;80:543-547.

38 Igarashi T, Murakami S, Takahashi H, et al. Changes on distribution of CD4+/CD45RA - and CD8+/CD11cells in tumor-infiltrating lymphocytes of renal cell carcinoma associated with tumor progression. Eur Urol 1992;22:323-328.

39 Cammarota G, Scheirle A, Takacs B, et al. Identification of a CD4 binding site on the beta 2 domain of HLA-DR molecules. Nature 1992;356:799-801.

40 Potter TA, Rajan TV, Dick II RF, et al. Substitution at residue 227 of $\mathrm{H}-2$ class $\mathrm{I}$ molecules abrogates recognition by CD8-dependent, but not CD8-independent, cytotoxic T lymphocytes. Nature 1989;337: 73-75.

41 Ward PL, Koeppen HK, Hurteau T, et al. Major histocompatibility complex class I and unique antigen expression by murine tumors that escaped from CD8+ T-cell-dependent surveillance. Cancer Res 1990;50:3851-3858.

42 Kripke ML. Antigenicity of murine skin tumors induced by ultraviolet light. J Natl Cancer Inst 1974; 53:1333-1336.

43 Spellman CW, Daynes RA. Ultraviolet light, tumors, and suppressor T cells. Hum Pathol 1981;12:299-301.

44 Leclerc JC, Gomard E, Levy JP. Cell-mediated reaction against tumors induced by oncornaviruses. I. Kinetics and specificity of the immune response in murine sarcoma virus (MSV)-induced tumors and transplanted lymphomas. Int J Cancer 1972;10:589-601.

45 Tevethia SS, Blasecki JW, Vaneck G, et al. Requirement of thymus-derived theta-positive lymphocytes for rejection of DNA virus (SV 40) tumors in mice. J Immunol 1974;113:1417-1423.

46 Cheever MA, Thompson DB, Klarnet JP, et al. Antigen-driven long term-cultured T cells proliferate in vivo, distribute widely, mediate specific tumor therapy, and persist long-term as functional memory T cells. J Exp Med 1986;163:1100-1112.

47 Rouse BT, Rollinghoff M, Warner NL. Anti-theta serum-induced supression of the cellular transfer of tumour-specific immunity to a syngeneic plasma cell tumour. Nat New Biol 1972;238:116-117.

48 Mukherji B, MacAlister TJ. Clonal analysis of cytotoxic T cell response against human melanoma. J Exp Med 1983;158:240-245.

49 Knuth A, Danowski B, Oettgen HF, et al. T-cellmediated cytotoxicity against autologous malignant melanoma: analysis with interleukin 2-dependent T-cell cultures. Proc Natl Acad Sci USA 1984;81: 3511-3515.

50 Klein E, Vanky F, Galili U, et al. Separation and characteristics of tumor-infiltrating lymphocytes in man. Contemp Top Immunobiol 1980;10:79-107.

51 Fossati G, Anichini A, Parmiani G. Melanoma cell lysis by human CTL clones: differential involvement of T3, T8 and HLA antigens. Int J Cancer 1987;39: 689-694.

52 Rosenberg SA. Progress in human tumour immunology and immunotherapy. Nature 2001;411:380-384.

53 Rosenberg SA, Yang JC, Restifo NP. Cancer immunotherapy: moving beyond current vaccines. Nat Med 2004;10:909-915.

54 Dudley ME, Wunderlich JR, Robbins PF, et al. Cancer regression and autoimmunity in patients after clonal repopulation with antitumor lymphocytes. Science 2002;298:850-854.
55 Dudley ME, Rosenberg SA. Adoptive-cell-transfer therapy for the treatment of patients with cancer. Nat Rev Cancer 2003;3:666-675.

56 Robins RA. T-cell responses at the host: tumour interface. Biochim Biophys Acta 1986;865:289-305.

57 Fearon ER, Pardoll DM, Itaya T, et al. Interleukin-2 production by tumor cells bypasses $\mathrm{T}$ helper function in the generation of an antitumor response. Cell 1990; 60:397-403.

58 Golumbek PT, Lazenby AJ, Levitsky HI, et al. Treatment of established renal cancer by tumor cells engineered to secrete interleukin-4. Science 1991;254: 713-716.

59 Dranoff G, Jaffee E, Lazenby A, et al. Vaccination with irradiated tumor cells engineered to secrete murine granulocyte-macrophage colony-stimulating factor stimulates potent, specific, and long-lasting antitumor immunity. Proc Natl Acad Sci USA 1993;90: 3539-3543.

60 Lin KY, Guarnieri FG, Staveley-O'Carroll KF, et al. Treatment of established tumors with a novel vaccine that enhances major histocompatibility class II presentation of tumor antigen. Cancer Res 1996;56: 21-26.

61 Noguchi Y, Richards EC, Chen YT, et al. Influence of interleukin 12 on p53 peptide vaccination against established Meth A sarcoma. Proc Natl Acad Sci USA 1995;92:2219-2223.

62 Feltkamp MC, Smits HL, Vierboom MP, et al. Vaccination with cytotoxic $\mathrm{T}$ lymphocyte epitopecontaining peptide protects against a tumor induced by human papillomavirus type 16-transformed cells. Eur J Immunol 1993;23:2242-2249.

63 Levitsky HI, Lazenby A, Hayashi RJ, et al. In vivo priming of two distinct antitumor effector populations: the role of MHC class I expression. J Exp Med 1994;179:1215-1224.

64 Ostrand-Rosenberg S. Tumor immunotherapy: the tumor cell as an antigen-presenting cell. Curr Opin Immunol 1994;6:722-727.

65 Pulaski BA, McAdam AJ, Hutter EK, et al. Interleukin 3 enhances development of tumor-reactive cytotoxic cells by a CD4-dependent mechanism. Cancer Res 1993;53:2112-2117.

66 Cavallo F, Giovarelli M, Gulino A, et al. Role of neutrophils and CD4+ T lymphocytes in the primary and memory response to nonimmunogenic murine mammary adenocarcinoma made immunogenic by IL-2 gene. J Immunol 1992;149:3627-3635.

67 Hock H, Dorsch M, Diamantstein T, et al. Interleukin 7 induces CD4+ T cell-dependent tumor rejection. J Exp Med 1991;174:1291-1298.

68 Pan ZK, Ikonomidis G, Pardoll D, et al. Regression of established tumors in mice mediated by the oral administration of a recombinant Listeria monocytogenes vaccine. Cancer Res 1995;55:4776-4779.

69 Pardoll DM, Topalian SL. The role of CD4+ T cell responses in antitumor immunity. Curr Opin Immunol 1998;10:588-594.

70 Monach PA, Meredith SC, Siegel CT, et al. A unique tumor antigen produced by a single amino acid substitution. Immunity 1995;2:45-59.

71 Beck-Engeser GB, Monach PA, Mumberg D, et al. Point mutation in essential genes with loss or mutation of the second allele: relevance to the retention of tumor-specific antigens. J Exp Med 2001; 194:285-300. 
72 Awwad M, North RJ. Immunologically mediated regression of a murine lymphoma after treatment with anti-L3T4 antibody. A consequence of removing L3T4+ suppressor $\mathrm{T}$ cells from a host generating predominantly Lyt-2+ $\mathrm{T}$ cell-mediated immunity. J Exp Med 1988;168:2193-2206.

73 Berendt MJ, North RJ. T-cell-mediated suppression of anti-tumor immunity. An explanation for progressive growth of an immunogenic tumor. J Exp Med 1980; 151:69-80.

74 Bursuker I, North RJ. Generation and decay of the immune response to a progressive fibrosarcoma. II. Failure to demonstrate postexcision immunity after the onset of T cell-mediated suppression of immunity. J Exp Med 1984;159:1312-1321.

75 Wang HY, Lee DA, Peng G, et al. Tumor-specific human $\mathrm{CD} 4+$ regulatory $\mathrm{T}$ cells and their ligands: implications for immunotherapy. Immunity 2004;20: 107-118.

76 Dieckmann D, Plottner H, Berchtold S, et al. Ex vivo isolation and characterization of CD4(+)CD25(+) T cells with regulatory properties from human blood. J Exp Med 2001;193:1303-1310.

77 Liyanage UK, Moore TT, Joo HG, et al. Prevalence of regulatory T cells is increased in peripheral blood and tumor microenvironment of patients with pancreas or breast adenocarcinoma. J Immunol 2002;169: 2756-2761.

78 Woo EY, Chu CS, Goletz TJ, et al. Regulatory CD4(+)CD25(+) T cells in tumors from patients with early-stage non-small cell lung cancer and late-stage ovarian cancer. Cancer Res 2001;61:4766-4772.

79 Woo EY, Yeh H, Chu CS, et al. Cutting edge: regulatory $\mathrm{T}$ cells from lung cancer patients directly inhibit autologous $\mathrm{T}$ cell proliferation. J Immunol 2002;168:4272-4276.

80 Beatty G, Paterson Y. IFN-gamma-dependent inhibition of tumor angiogenesis by tumor-infiltrating CD4+ $\mathrm{T}$ cells requires tumor responsiveness to IFN-gamma. J Immunol 2001;166:2276-2282.

81 Fujiwara H, Fukuzawa M, Yoshioka T, et al. The role of tumor-specific Lyt-1+2- $\mathrm{T}$ cells in eradicating tumor cells in vivo. I. Lyt-1+2- $\mathrm{T}$ cells do not necessarily require recruitment of host's cytotoxic $\mathrm{T}$ cell precursors for implementation of in vivo immunity. J Immunol 1984;133:1671-1676.

82 Greenberg PD, Cheever MA, Fefer A. Eradication of disseminated murine leukemia by chemoimmunotherapy with cyclophosphamide and adoptively transferred immune syngeneic Lyt-1+2- lymphocytes. J Exp Med 1981;154:952-963.

83 Mumberg D, Monach PA, Wanderling S, et al. CD4(+) T cells eliminate MHC class II-negative cancer cells in vivo by indirect effects of IFN-gamma. Proc Natl Acad Sci USA 1999;96:8633-8638.

84 Beatty GL, Paterson Y. IFN-gamma can promote tumor evasion of the immune system in vivo by downregulating cellular levels of an endogenous tumor antigen. J Immunol 2000;165:5502-5508.

85 Huang AY, Golumbek P, Ahmadzadeh M, et al. Role of bone marrow-derived cells in presenting MHC class Irestricted tumor antigens. Science 1994;264:961-965.

86 Huang AY, Bruce AT, Pardoll DM, et al. In vivo crosspriming of $\mathrm{MHC}$ class I-restricted antigens requires the TAP transporter. Immunity 1996;4:349-355.

87 Toes RE, Blom RJ, van der Voort E, et al. Protective antitumor immunity induced by immunization with completely allogeneic tumor cells. Cancer Res 1996;56:3782-3787.

$88 \mathrm{Yu}$ P, Spiotto MT, Lee Y, et al. Complementary role of CD4+ T cells and secondary lymphoid tissues for cross-presentation of tumor antigen to CD8+ T cells. J Exp Med 2003;197:985-995.

89 Spiotto MT, Yu P, Rowley DA, et al. Increasing tumor antigen expression overcomes 'ignorance' to solid tumors via crosspresentation by bone marrow-derived stromal cells. Immunity 2002;17:737-747.

90 Ridge JP, Di Rosa F, Matzinger P. A conditioned dendritic cell can be a temporal bridge between a CD4+ T-helper and a T-killer cell. Nature 1998;393:474-478.

91 Shinde S, Wu Y, Guo Y, et al. CD40L is important for induction of, but not response to, costimulatory activity. ICAM-1 as the second costimulatory molecule rapidly up-regulated by CD40L. J Immunol 1996; 157:2764-2768.

92 Cella M, Scheidegger D, Palmer-Lehmann K, et al. Ligation of CD40 on dendritic cells triggers production of high levels of interleukin-12 and enhances T cell stimulatory capacity: T-T help via APC activation. J Exp Med 1996;184:747-752.

93 Koch F, Stanzl U, Jennewein P, et al. High level IL-12 production by murine dendritic cells: upregulation via MHC class II and CD40 molecules and downregulation by IL-4 and IL-10. J Exp Med 1996;184: 741-746.

$94 \mathrm{Lu} \mathrm{Z,} \mathrm{Yuan} \mathrm{L,} \mathrm{Zhou} \mathrm{X,} \mathrm{et} \mathrm{al.} \mathrm{CD40-independent}$ pathways of $\mathrm{T}$ cell help for priming of CD8(+) cytotoxic T lymphocytes. J Exp Med 2000;191: 541-550.

95 Schoenberger SP, Toes RE, van der Voort EI, et al. T-cell help for cytotoxic T lymphocytes is mediated by CD40-CD40L interactions. Nature 1998;393: 480-483.

96 Bennett SR, Carbone FR, Karamalis F, et al. Help for cytotoxic-T-cell responses is mediated by CD40 signalling. Nature 1998;393:478-480.

97 Bennett SR, Carbone FR, Karamalis F, et al. Induction of a CD8+ cytotoxic T lymphocyte response by crosspriming requires cognate CD4+ T cell help. J Exp Med 1997;186:65-70.

98 Mackey MF, Gunn JR, Ting PP, et al. Protective immunity induced by tumor vaccines requires interaction between CD40 and its ligand, CD154. Cancer Res 1997;57:2569-2574.

99 Mackey MF, Gunn JR, Maliszewsky C, et al. Dendritic cells require maturation via CD40 to generate protective antitumor immunity. J Immunol 1998;161: 2094-2098.

100 Stevenson PG, Belz GT, Altman JD, et al. Virusspecific CD8(+) T cell numbers are maintained during gamma-herpesvirus reactivation in CD4-deficient mice. Proc Natl Acad Sci USA 1998;95:15565-15570.

101 MacDonald GH, Johnston RE. Role of dendritic cell targeting in Venezuelan equine encephalitis virus pathogenesis. J Virol 2000;74:914-922.

102 Wolkers MC, Stoetter G, Vyth-Dreese FA, et al. Redundancy of direct priming and cross-priming in tumor-specific CD8+ T cell responses. J Immunol 2001;167:3577-3584.

103 Shi Y, Zheng W, Rock KL. Cell injury releases endogenous adjuvants that stimulate cytotoxic T cell responses. Proc Natl Acad Sci USA 2000;97: 14590-14595. 
104 De Bruijn ML, Schumacher TN, Nieland JD, et al. Peptide loading of empty major histocompatibility complex molecules on RMA-S cells allows the induction of primary cytotoxic $\mathrm{T}$ lymphocyte responses. Eur J Immunol 1991;21:2963-2970.

105 Fayolle C, Abdel-Motal UM, Berg L, et al. Induction of cytotoxic T-cell response by optimal-length peptides does not require CD4+ T-cell help. Immunology 1996;89:41-45.

106 Schnell S, Young JW, Houghton AN, et al. Retrovirally transduced mouse dendritic cells require CD4+ $\mathrm{T}$ cell help to elicit antitumor immunity: implications for the clinical use of dendritic cells. J Immunol 2000;164:1243-1250.

107 Wolfers J, Lozier A, Raposo G, et al. Tumor-derived exosomes are a source of shared tumor rejection antigens for CTL cross-priming. Nat Med 2001;7: 297-303.

108 Tuting T, Steitz J, Bruck J, et al. Dendritic cell-based genetic immunization in mice with a recombinant adenovirus encoding murine TRP2 induces effective anti-melanoma immunity. J Gene Med 1999;1:400-406.

109 Fields RC, Shimizu K, Mule JJ. Murine dendritic cells pulsed with whole tumor lysates mediate potent antitumor immune responses in vitro and in vivo. Proc Natl Acad Sci USA 1998;95:9482-9487.

110 Porgador A, Gilboa E. Bone marrow-generated dendritic cells pulsed with a class I-restricted peptide are potent inducers of cytotoxic T lymphocytes. J Exp Med 1995;182:255-260.

111 Battegay M, Moskophidis D, Rahemtulla A, et al. Enhanced establishment of a virus carrier state in adult CD4+ T-cell-deficient mice. J Virol 1994;68: 4700-4704.

112 Matloubian M, Concepcion RJ, Ahmed R. CD4+ T cells are required to sustain CD8+ cytotoxic T-cell responses during chronic viral infection. J Virol 1994; 68:8056-8063.

113 Cardin RD, Brooks JW, Sarawar SR, et al. Progressive loss of CD8+ T cell-mediated control of a gammaherpesvirus in the absence of CD4+ T cells. J Exp Med 1996;184:863-871.

114 Zitvogel L, Mayordomo JI, Tjandrawan $\mathrm{T}$, et al. Therapy of murine tumors with tumor peptidepulsed dendritic cells: dependence on $\mathrm{T}$ cells, B7 costimulation, and $\mathrm{T}$ helper cell 1-associated cytokines. J Exp Med 1996;183:87-97.

115 Schomig A, Neumann FJ, Kastrati A, et al. A randomized comparison of antiplatelet and anticoagulant therapy after the placement of coronaryartery stents. N Engl J Med 1996;334:1084-1089.

116 Kast WM, Bronkhorst AM, de Waal LP, et al. Cooperation between cytotoxic and helper T lymphocytes in protection against lethal Sendai virus infection. Protection by $\mathrm{T}$ cells is MHC-restricted and MHC-regulated; a model for MHC-disease associations. J Exp Med 1986;164:723-738.

117 Bear HD, Susskind BM, Close KA, et al. Phenotype of syngeneic tumor-specific cytotoxic T-lymphocytes and requirements for their in vitro generation from tumor-bearing host and immune spleens. Cancer Res 1988;48:1422-1427.

118 Kast WM, Offringa R, Peters PJ, et al. Eradication of adenovirus E1-induced tumors by E1A-specific cytotoxic T lymphocytes. Cell 1989;59:603-614.

$119 \mathrm{Hu} \mathrm{HM}$, Winter H, Urba WJ, et al. Divergent roles for CD4+ $\mathrm{T}$ cells in the priming and effector/memory phases of adoptive immunotherapy. J Immunol 2000; 165:4246-4253.

120 Janssen EM, Lemmens EE, Wolfe T, et al. CD4+ T cells are required for secondary expansion and memory in CD8+ T lymphocytes. Nature 2003;421:852-856.

121 Shedlock DJ, Shen H. Requirement for CD4 T cell help in generating functional CD8 T cell memory. Science 2003;300:337-339.

122 Sun JC, Bevan MJ. Defective CD8 T cell memory following acute infection without CD4 T cell help. Science 2003;300:339-342.

123 Sun JC, Williams MA, Bevan MJ. CD4+ T cells are required for the maintenance, not programming, of memory CD8+ T cells after acute infection. Nat Immunol 2004;5:927-933.

124 Bevan MJ. Helping the CD8(+) T-cell response. Nat Rev Immunol 2004;4:595-602.

125 Di Rosa F, Matzinger P. Long-lasting CD8T cell memory in the absence of CD4 T cells or B cells. J Exp Med 1996;183:2153-2163.

126 Zajac AJ, Blattman JN, Murali-Krishna K, et al. Viral immune evasion due to persistence of activated $\mathrm{T}$ cells without effector function. J Exp Med 1998;188: 2205-2213.

127 Mosmann TR, Sad S. The expanding universe of T-cell subsets: Th1, Th2 and more. Immunol Today 1996;17:138-146.

128 Romagnani S. The Th1/Th2 paradigm. Immunol Today 1997;18:263-266.

129 York IA, Goldberg AL, Mo XY, et al. Proteolysis and class I major histocompatibility complex antigen presentation. Immunol Rev 1999;172:49-66.

130 Tsung K, Meko JB, Peplinski GR, et al. IL-12 induces $\mathrm{T}$ helper 1-directed antitumor response. J Immunol 1997;158:3359-3365.

131 Aruga A, Aruga E, Tanigawa K, et al. Type 1 vs type 2 cytokine release by Vbeta $\mathrm{T}$ cell subpopulations determines in vivo antitumor reactivity: IL-10 mediates a suppressive role. J Immunol 1997;159:664-673.

132 Lowes MA, Bishop GA, Crotty K, et al. T helper 1 cytokine mRNA is increased in spontaneously regressing primary melanomas. J Invest Dermatol 1997;108: 914-919.

133 Fallarino F, Gajewski TF. Cutting edge: differentiation of antitumor CTL in vivo requires host expression of Stat1. J Immunol 1999;163:4109-4113.

134 Kacha AK, Fallarino F, Markiewicz MA, et al. Cutting edge: spontaneous rejection of poorly immunogenic P1.HTR tumors by Stat6-deficient mice. J Immunol 2000;165:6024-6028.

135 Kobayashi M, Kobayashi H, Pollard RB, et al. A pathogenic role of Th2 cells and their cytokine products on the pulmonary metastasis of murine B16 melanoma. J Immunol 1998;160:5869-5873.

136 Ostrand-Rosenberg S, Grusby MJ, Clements VK. Cutting edge: STAT6-deficient mice have enhanced tumor immunity to primary and metastatic mammary carcinoma. J Immunol 2000;165:6015-6019.

137 Pellegrini P, Berghella AM, Del Beato T, et al. Disregulation in TH1 and $\mathrm{TH} 2$ subsets of CD4+ T cells in peripheral blood of colorectal cancer patients and involvement in cancer establishment and progression. Cancer Immunol Immunother 1996;42:1-8.

$138 \mathrm{Hu} \mathrm{HM}$, Urba WJ, Fox BA. Gene-modified tumor vaccine with therapeutic potential shifts tumorspecific $\mathrm{T}$ cell response from a type 2 to a type 1 cytokine profile. J Immunol 1998;161:3033-3041. 
139 Tepper RI, Pattengale PK, Leder P. Murine interleukin-4 displays potent anti-tumor activity in vivo. Cell 1989;57:503-512.

140 Allione A, Consalvo M, Nanni P, et al. Immunizing and curative potential of replicating and nonreplicating murine mammary adenocarcinoma cells engineered with interleukin (IL)-2, IL-4, IL-6, IL-7, IL-10, tumor necrosis factor alpha, granulocyte-macrophage colony-stimulating factor, and gamma-interferon gene or admixed with conventional adjuvants. Cancer Res 1994;54:6022-6026.

141 Shen Y, Fujimoto S. A tumor-specific Th2 clone initiating tumor rejection via primed CD8+ cytotoxic T-lymphocyte activation in mice. Cancer Res 1996;56: 5005-5011.

142 Nishimura T, Iwakabe K, Sekimoto M, et al. Distinct role of antigen-specific T helper type 1 (Th1) and Th2 cells in tumor eradication in vivo. J Exp Med 1999; 190:617-627.

143 Fallarino F, Grohmann U, Bianchi R, et al. Th1 and Th2 cell clones to a poorly immunogenic tumor antigen initiate CD8+ T cell-dependent tumor eradication in vivo. J Immunol 2000;165:5495-5501.

144 Klugewitz K, Scheffold A, Radbruch A, et al. Transfer of IFNgamma-depleted CD4(+) T cells together with CD8(+) $\mathrm{T}$ cells leads to rejection of murine kidney sarcoma in mice. Int J Cancer 2000;87:673-679.

145 Hung K, Hayashi R, Lafond-Walker A, et al. The central role of CD4(+) $\mathrm{T}$ cells in the antitumor immune response. J Exp Med 1998;188:2357-2368.

146 Sakaguchi S, Fukuma K, Kuribayashi K, et al. Organspecific autoimmune diseases induced in mice by elimination of T cell subset. I. Evidence for the active participation of $\mathrm{T}$ cells in natural self-tolerance; deficit of a $\mathrm{T}$ cell subset as a possible cause of autoimmune disease. J Exp Med 1985;161:72-87.

147 Sugihara S, Izumi Y, Yoshioka T, et al. Autoimmune thyroiditis induced in mice depleted of particular $\mathrm{T}$ cell subsets. I. Requirement of Lyt-1 dull L3T4 bright normal $\mathrm{T}$ cells for the induction of thyroiditis. J Immunol 1988;141:105-113.

148 Sakaguchi S, Sakaguchi N, Asano M, et al. Immunologic self-tolerance maintained by activated $\mathrm{T}$ cells expressing IL-2 receptor alpha-chains (CD25). Breakdown of a single mechanism of self-tolerance causes various autoimmune diseases. J Immunol 1995;155: 1151-1164.

149 Bach JF, Francois Bach J. Regulatory T cells under scrutiny. Nat Rev Immunol 2003;3:189-198.

150 Belkaid Y, Piccirillo CA, Mendez S, et al. CD4+CD25+ regulatory $\mathrm{T}$ cells control Leishmania major persistence and immunity. Nature 2002;420:502-507.

151 Maloy KJ, Powrie F. Regulatory T cells in the control of immune pathology. Nat Immunol 2001;2:816-822.

152 Sakaguchi S. Naturally arising CD4+ regulatory T cells for immunologic self-tolerance and negative control of immune responses. Annu Rev Immunol 2004;22:531-562.

153 Shevach EM. CD4+ CD25+ suppressor T cells: more questions than answers. Nat Rev Immunol 2002;2: 389-400.

154 Apostolou I, Sarukhan A, Klein L, et al. Origin of regulatory T cells with known specificity for antigen. Nat Immunol 2002;3:756-763.

155 Curotto de Lafaille MA, Lafaille JJ. CD4(+) regulatory $\mathrm{T}$ cells in autoimmunity and allergy. Curr Opin Immunol 2002;14:771-778.
156 Furtado GC, Olivares-Villagomez D, Curotto de Lafaille MA, et al. Regulatory T cells in spontaneous autoimmune encephalomyelitis. Immunol Rev 2001; 182:122-134.

157 Levings MK, Roncarolo MG. T-regulatory 1 cells: a novel subset of CD4 T cells with immunoregulatory properties. J Allergy Clin Immunol 2000;106(Part 2): S109-S112.

158 O’Garra A, Vieira PL, Vieira P, et al. IL-10-producing and naturally occurring CD4+ Tregs: limiting collateral damage. J Clin Invest 2004;114:1372-1378.

159 Gorelik L, Flavell RA. Abrogation of TGFbeta signaling in T cells leads to spontaneous T cell differentiation and autoimmune disease. Immunity 2000;12: 171-181.

160 Seddon B, Mason D. Regulatory T cells in the control of autoimmunity: the essential role of transforming growth factor beta and interleukin 4 in the prevention of autoimmune thyroiditis in rats by peripheral CD4(+)CD45RC- cells and CD4(+)CD8(-) thymocytes. J Exp Med 1999;189:279-288.

161 Zhai Y, Kupiec-Weglinski JW. What is the role of regulatory $\mathrm{T}$ cells in transplantation tolerance? Curr Opin Immunol 1999;11:497-503.

162 Sakaguchi S, Sakaguchi N, Shimizu J, et al. Immunologic tolerance maintained by CD25+CD4+ regulatory T cells: their common role in controlling autoimmunity, tumor immunity, and transplantation tolerance. Immunol Rev 2001;182:18-32.

163 Wood KJ, Sakaguchi S. Regulatory T cells in transplantation tolerance. Nat Rev Immunol 2003;3: 199-210.

164 Bennett CL, Christie J, Ramsdell F, et al. The immune dysregulation, polyendocrinopathy, enteropathy, X-linked syndrome (IPEX) is caused by mutations of FOXP3. Nat Genet 2001;27:20-21.

165 Brunkow ME, Jeffery EW, Hjerrild KA, et al. Disruption of a new forkhead/winged-helix protein, scurfin, results in the fatal lymphoproliferative disorder of the scurfy mouse. Nat Genet 2001;27:68-73.

166 Wildin RS, Ramsdell F, Peake J, et al. X-linked neonatal diabetes mellitus, enteropathy and endocrinopathy syndrome is the human equivalent of mouse scurfy. Nat Genet 2001;27:18-20.

167 Khattri R, Cox T, Yasayko SA, et al. An essential role for Scurfin in CD4+CD25+ T regulatory cells. Nat Immunol 2003;4:337-342.

168 Fontenot JD, Gavin MA, Rudensky AY. Foxp3 programs the development and function of CD4+CD25+ regulatory T cells. Nat Immunol 2003;4:330-336.

169 Hori S, Nomura T, Sakaguchi S. Control of regulatory T cell development by the transcription factor Foxp3. Science 2003;299:1057-1061.

170 Walker MR, Kasprowicz DJ, Gersuk VH, et al. Induction of FoxP3 and acquisition of $\mathrm{T}$ regulatory activity by stimulated human CD4+CD25- T cells. J Clin Invest 2003;112:1437-1443.

171 Chen W, Jin W, Hardegen N, et al. Conversion of peripheral CD4+CD25 - naive T cells to CD4+CD25+ regulatory $\mathrm{T}$ cells by TGF-beta induction of transcription factor Foxp3. J Exp Med 2003;198:1875-1886.

172 Cosmi L, Liotta F, Lazzeri E, et al. Human CD8+ CD25+ thymocytes share phenotypic and functional features with CD4+CD25+ regulatory thymocytes. Blood 2003;102:4107-4114.

173 Manavalan JS, Kim-Schulze S, Scotto L, et al. Alloantigen specific CD8+CD28- FOXP3+ T suppressor 
cells induce ILT3+ ILT4+ tolerogenic endothelial cells, inhibiting alloreactivity. Int Immunol 2004;16: 1055-1068.

174 Daniel D, Meyer-Morse N, Bergsland EK, et al. Immune enhancement of skin carcinogenesis by CD4+ T cells. J Exp Med 2003;197:1017-1028.

175 Siegel CT, Schreiber K, Meredith SC, et al. Enhanced growth of primary tumors in cancer-prone mice after immunization against the mutant region of an inherited oncoprotein. J Exp Med 2000;191: 1945-1956.

176 Sasada T, Kimura M, Yoshida Y, et al. CD4+CD25+ regulatory $\mathrm{T}$ cells in patients with gastrointestinal malignancies: possible involvement of regulatory $\mathrm{T}$ cells in disease progression. Cancer 2003;98: 1089-1099.

177 Marshall NA, Christie LE, Munro LR, et al. Immunosuppressive regulatory $\mathrm{T}$ cells are abundant in the reactive lymphocytes of Hodgkin lymphoma. Blood 2004;103:1755-1762.

178 Zhou G, Lu Z, McCadden JD, et al. Reciprocal changes in tumor antigenicity and antigen-specific T cell function during tumor progression. J Exp Med 2004;200:1581-1592.

179 Ettinger $\mathrm{R}$. The role of tumor necrosis factor and lymphotoxin in lymphoid organ development. Curr Top Microbiol Immunol 2000;251:203-210.

$180 \mathrm{Fu}$ YX, Chaplin DD. Development and maturation of secondary lymphoid tissues. Annu Rev Immunol 1999;17:399-433.

181 Kim D, Mebius RE, MacMicking JD, et al. Regulation of peripheral lymph node genesis by the tumor necrosis factor family member TRANCE. J Exp Med 2000;192:1467-1478.

182 Mauri DN, Ebner R, Montgomery RI, et al. LIGHT, a new member of the TNF superfamily, and lymphotoxin alpha are ligands for herpesvirus entry mediator. Immunity 1998;8:21-30.

$183 \mathrm{Wu} \mathrm{Q}$, Wang Y, Wang J, et al. The requirement of membrane lymphotoxin for the presence of dendritic cells in lymphoid tissues. J Exp Med 1999;190: 629-638.

184 Ngo VN, Korner H, Gunn MD, et al. Lymphotoxin alpha/beta and tumor necrosis factor are required for stromal cell expression of homing chemokines in B and $\mathrm{T}$ cell areas of the spleen. J Exp Med 1999;189: 403-412.

185 Spriggs DR, Sherman ML, Michie H, et al. Recombinant human tumor necrosis factor administered as a 24-h intravenous infusion. A phase I and pharmacologic study. J Natl Cancer Inst 1988;80:1039-1044.

186 Schrama D, thor Straten P, Fischer WH, et al. Targeting of lymphotoxin-alpha to the tumor elicits an efficient immune response associated with induction of peripheral lymphoid-like tissue. Immunity 2001;14:111-121.

187 Rooney IA, Butrovich KD, Glass AA, et al. The lymphotoxin-beta receptor is necessary and sufficient for LIGHT-mediated apoptosis of tumor cells. J Biol Chem 2000;275:14307-14315.

188 Tamada K, Shimozaki K, Chapoval AI, et al. Modulation of T-cell-mediated immunity in tumor and graftversus-host disease models through the LIGHT co-stimulatory pathway. Nat Med 2000;6:283-289.

189 Zhai Y, Guo R, Hsu TL, et al. LIGHT, a novel ligand for lymphotoxin beta receptor and TR2/HVEM induces apoptosis and suppresses in vivo tumor formation via gene transfer. J Clin Invest 1998;102: 1142-1151.

190 Wang J, Chun T, Lo JC, et al. The critical role of LIGHT, a TNF family member, in T cell development. J Immunol 2001;167:5099-5105.

191 Wang J, Foster A, Chin R, et al. The complementation of lymphotoxin deficiency with LIGHT, a newly discovered TNF family member, for the restoration of secondary lymphoid structure and function. Eur J Immunol 2002;32:1969-1979.

$192 \mathrm{Yu}$ P, Lee Y, Liu W, et al. Priming of naive T cells inside tumors leads to eradication of established tumors. Nat Immunol 2004;5:141-149. 